\title{
Evolving marginal terranes during Neoproterozoic supercontinent reorganisation: constraints from the Bemarivo Belt in northern Madagascar
}

\author{
Sheree E. Armistead ${ }^{1 *}$, Alan S. Collins ${ }^{1}$, Justin L. Payne ${ }^{2}$, Grant M. Cox ${ }^{1}$, Andrew S. \\ Merdith $^{3}$, John D. Foden ${ }^{1}$, Théodore Razakamanana ${ }^{4}$, Bert De Waele ${ }^{5,6}$ \\ ${ }^{1}$ Centre for Tectonics, Resources and Exploration (TRaX), Department of Earth Sciences, The University \\ of Adelaide, SA 5005, Australia \\ ${ }^{2}$ Centre for Tectonics, Resources and Exploration (TraX), School of Built and Natural Environments, \\ The University of South Australia, SA 5001, Australia \\ ${ }^{3}$ LGL-TPE, Université Lyon 1, 69100, Villeurbanne, France \\ ${ }^{4}$ Département des Sciences de la Terre, Université de Toliara, Toliara, Madagascar \\ ${ }^{5}$ SRK Consulting, 10 Richardson Street, West Perth, WA 6005, Australia \\ ${ }^{6}$ Department of Applied Geology, Curtin University, WA, Australia \\ Corresponding author: Sheree Armistead (sheree.armistead@adelaide.edu.au)
}

\section{Key Points:}

- New model linking northern Madagascar, Seychelles, NW India, Oman, south China at c. $750 \mathrm{Ma}$

- New zircon Hf and O isotope data from the Bemarivo Belt in northern Madagascar indicating that the northern Bemarivo Belt is juvenile

- Southern Bemarivo Belt has evolved Hf isotope signatures and likely links with central Madagascar magmatic suites

\section{This manuscript is under review in TECTONICS.}

Please note that subsequent versions of this manuscript will have slightly different content. If accepted, the final version of this manuscript will be available via the 'Peer-reviewed

Publication DOI' link on the right-hand side of this webpage. Please feel free to contact any of the authors, we welcome your feedback! :) 


\section{Abstract}

Madagascar is important for unravelling the geodynamic evolution of the transition between the Rodinia and Gondwana supercontinents as it contains several suites of c. 850-700 Ma magmatic rocks that have been postulated to correlate with other ex-Rodinia terranes. The Bemarivo Belt of northern Madagascar contains the youngest suite of these magmatic rocks that date to c. 750-700 Ma. We present zircon Hf and O isotope data from the Bemarivo Belt to understand its place in the Neoproterozoic plate tectonic reconfiguration. We demonstrate that the northern Bemarivo Belt is distinctly different from the southern Bemarivo Belt. Magmatic rocks of the southern Bemarivo Belt and Anaboriana Belt are characterised by evolved $\varepsilon_{\mathrm{Hf}}(\mathrm{t})$ signatures and a range of $\delta^{18} \mathrm{O}$ values, similar to the Imorona-Itsindro Suite of central Madagascar. Magmatic rocks from the southern Bemarivo Belt, Anaboriana Belt and Imorona-Itsindro Suite likely formed together in the same long-lived volcanic arc. In contrast, the northern Bemarivo Belt contains juvenile $\varepsilon_{\mathrm{Hf}}(\mathrm{t})$ and mantle-like $\delta^{18} \mathrm{O}$ values, with no probable link to the rest of Madagascar. We propose that the northern Bemarivo Belt formed in a juvenile arc system that included the Seychelles, Malani Igneous Suite of northwest India, Oman, and the Yangtze Belt of south China, outboard from continental India and south China. The final assembly of northern Madagascar and amalgamation of the northern and southern Bemarivo terranes occurred along the Antsaba subduction zone, with final assembly constrained by the c. 520 Ma post-tectonic Maevarano Suite.

\section{Introduction}

Reconstructing the tectonic geography of the ancient Earth and building a full-plate tectonic reconstruction for the globe in deep time is critically dependent on mapping the distribution of plate tectonic sensitive rocks through time (e.g. Merdith et al., 2017). A key goal is to understand the supercontinent cycle, and whether it operates as a simple pulse (e.g. Nance et al., 2014) or as a two-stage process starting with supercontinent initiation, followed by progressive accretion (e.g. Condie, 2002). This insight requires a detailed knowledge of the location and duration of the critical plate-margin geological events formed at either subduction zones or rifts (e.g. Mallard et al., 2016). The Neoproterozoic, in particular, is a critical period because it sees the major transition from the Nuna/Rodinia supercontinent cycle to the accretion and amalgamation of Gondwana/Pangaea (Merdith et al., 2018). Much of the evidence for this billion-year timescale plate reconfiguration is found in the East African Orogen that formed as the Mozambique Ocean closed and Neoproterozoic India collided with the Congo Craton to form central Gondwana (Armistead et al., 2017; Collins and Pisarevsky, 
2005; Fritz et al., 2013). Madagascar was located in the centre of the East African Orogen and provides an ideal natural laboratory to study how the active margins that consumed the Mozambique Ocean evolved to form the supercontinent Gondwana. Of particular interest and contention, is how and when the Archean nucleus of Madagascar amalgamated with the Dharwar Craton of India to the east, and East Africa to the west, as well as with smaller continental blocks of equivocal origin. One of these blocks- the Bemarivo Belt of northern Madagascar-is composed of Neoproterozoic rocks spanning c. 750-700 Ma. Its evolution and amalgamation with the rest of Madagascar is poorly understood and is the focus of this study.

Madagascar is made up of several terranes spanning from Archean to recent times. The centre of Madagascar is made up of the Antananarivo Craton, which is composed of c. $2500 \mathrm{Ma}$ magmatic gneisses (Collins and Windley, 2002; Kröner et al., 2000). To the east of this craton are the Antongil and Masora cratons. These contain rocks that are c. $3100 \mathrm{Ma}$ and are likely a continuation of the Dharwar Craton of India (Armistead et al., 2017; Schofield et al., 2010; Tucker et al., 1999b). To the southwest of the Antananarivo Craton is the Itremo Group, made up of quartzites, schists and marbles with a maximum depositional age of c. $1600 \mathrm{Ma}$ (Cox et al., 1998; Fernandez et al., 2003). To the southwest of this, is the Ikalamavony Group, similarly made up of quartzites, schists and marbles, but with a maximum depositional age of c. 1000 Ma. To the south of these metasedimentary sequences are the Proterozoic Anosyen, Androyen and Vohibory terranes (Boger et al., 2014; Emmel et al., 2008; Jöns and Schenk, 2007).

North of the Antananarivo Craton is the Bemarivo Belt, made up of the Paleoproterozoic Sahantaha Group, and intruded by c. 750-700 Ma magmatic rocks with a range of geochemical compositions (Thomas et al., 2009). Separating the Antananarivo Craton from the Bemarivo Belt, is the Anaboriana-Manampotsy belt-an interpreted late Neoproterozoic sequence of gneisses thought to represent the suture between Madagascar and the Dharwar Craton of India (Collins and Windley, 2002).

Northern Madagascar comprises the c. 3100 Ma Antongil Craton, the c. $2500 \mathrm{Ma}$ Antananarivo Craton and the c. 750-700 Ma Bemarivo Belt (Figure 1), all of which have debatable geological histories. It is well documented that the Antongil Craton of northern Madagascar shares many characteristics with the Dharwar Craton of India, and that these two terranes were probably contiguous until the breakup of Gondwana (Armistead et al., 2017; Bauer et al., 2011; Collins and Windley, 2002; Schofield et al., 2010). However, the timing of collision between the Antongil-Dharwar Craton of India and the rest of Madagascar is a 
contentious topic. Two end-member models are generally evaluated for the amalgamation of Madagascar; 1) the Antongil(Dharwar)-Madagascar collision occurred in the late Archean, and central Madagascar and the Dharwar Craton have existed as "the Greater Dharwar Craton" from then until the breakup of Gondwana (Tucker et al., 2011); or 2) Antongil(Dharwar) and central Madagascar were separate terranes that were sutured during the major EdiacaranCambrian Malagasy Orogeny, marked by the Betsimisaraka Suture (Collins and Windley, 2002). Understanding the timing and nature of the assembly of northern Madagascar will provide important constraints on the amalgamation of Madagascar more broadly.

\subsection{Regional Geology of the Bemarivo Belt}

A World Bank Project in Madagascar led to the collection of a substantial dataset of geochemical, geochronological and stratigraphic data from northern Madagascar (BGS-USGSGLW, 2008). The Bemarivo Belt has loosely been divided into two terranes separated by the east-west trending Antsaba Shear Zone (Figure 1)(Thomas et al., 2009).

The southern Bemarivo Belt contains the Sahantaha Group, a metasedimentary sequence derived from Paleoproterozoic sources. This sequence has been interpreted as the passive margin sequence to the Antananarivo Craton. The Sahantaha Group contains similar rock types, and detrital zircons with similar dates to the Itremo Group of central Madagascar (BGSUSGS-GLW, 2008; Cox et al., 1998; Cox et al., 2004; De Waele et al., 2011; Fitzsimons and Hulscher, 2005). The Sahantaha Group is intruded by the c. 750 Ma Antsirabe Nord Suite, a plutonic suite ranging from gabbro to granite (Thomas et al., 2009).

The northern Bemarivo Belt contains a component of metamorphosed Archean schist and gneiss-the c. 2477 Ma Betsiaka Group, although outcrops of these rocks are scarce and geographically restricted to the northwest margin of the Bemarivo Belt (Thomas et al., 2009). The Betsiaka Group is in fault-contact with the northern Bemarivo units and possibly represents a faulted block of the Antananarivo Domain. Two volcano-sedimentary groups were deposited in the northern Bemarivo Belt at c. 750-720 Ma. The high-grade, amphibolitefacies volcano-sedimentary Milanoa Group has a maximum depositional age of c. $750 \mathrm{Ma}$, and the low-grade, greenschist to lower amphibolite facies, Daraina Group has an extrusive age of c. 740-730 Ma (Thomas et al., 2009). These groups are intruded by arc-related rocks of the Manambato Suite, which comprises c. 718-705 Ma magmatic rocks (Thomas et al., 2009).

Much of northern Madagascar is intruded by the c. 530 Ma Maevarano Suite, interpreted as post-tectonic granites that formed due to orogenic collapse of the East African Orogen 
(Goodenough et al., 2010). This suite has been used as a maximum age constraint on the final assembly of northern Madagascar, based on the interpretation that it is exposed in all terranes of northern Madagascar (Goodenough et al., 2010; Thomas et al., 2009).

When considered as a single coherent terrane, the northern and southern Bemarivo belts have been interpreted as a juvenile arc terrane that was accreted to the Antananarivo Craton along a Neoproterozoic-Cambrian suture (Thomas et al., 2009). Juvenile Nd data was reported in abstract only (Tucker et al., 1999a) and has been used as evidence for the juvenile nature of both the northern and southern Bemarivo belts. However, sample locations were not reported and it remains unclear whether these samples were collected from the northern or southern Bemarivo Belt. Extensive whole-rock geochemistry data collected through the World Bank Project (BGS-USGS-GLW, 2008; Thomas et al., 2009) suggest that much of the Bemarivo Belt formed from volcanic arc processes. This interpretation was based on Y-Nb tectonic discrimination diagrams, and the calc-alkaline nature of the rocks preserved in the Bemarivo Belt. However, a lack of published isotopic data beyond zircon $\mathrm{U}-\mathrm{Pb}$ geochronology for this region limits our ability to fully understand the magma processes and crustal assimilation involved in the evolution of the Bemarivo Belt. Understanding the isotopic nature of these magmatic suites in terms of their crustal versus mantle components, is important for correlating them with other age-equivalent terranes. The age-equivalent c. 850-750 Ma Imorona-Itsindro magmatic suite is widespread in central Madagascar (Archibald et al., 2016; Archibald et al., 2017b; Zhou et al., 2018), and may form a continuum with the Bemarivo Belt. Likewise, there are age-equivalent terranes in the Seychelles, the Malani Igneous Suite of northwest India and the Yangtze Belt of south China. However, isotopic data, in addition to conventional $\mathrm{U}-\mathrm{Pb}$ zircon dating is needed to test the robustness of these correlations. We have collected $\mathrm{Hf}$ and $\mathrm{O}$ isotope data from zircon within the Bemarivo Belt of northern Madagascar to characterise the evolution of this terrane and compare it to terranes elsewhere in Madagascar and globally. Integrating this dataset within a plate tectonic framework using GPlates reconstruction software, allows us to assess tectonic models both temporally and spatially. The results of this study are important for supercontinent reconstructions of both Rodinia and Gondwana. 


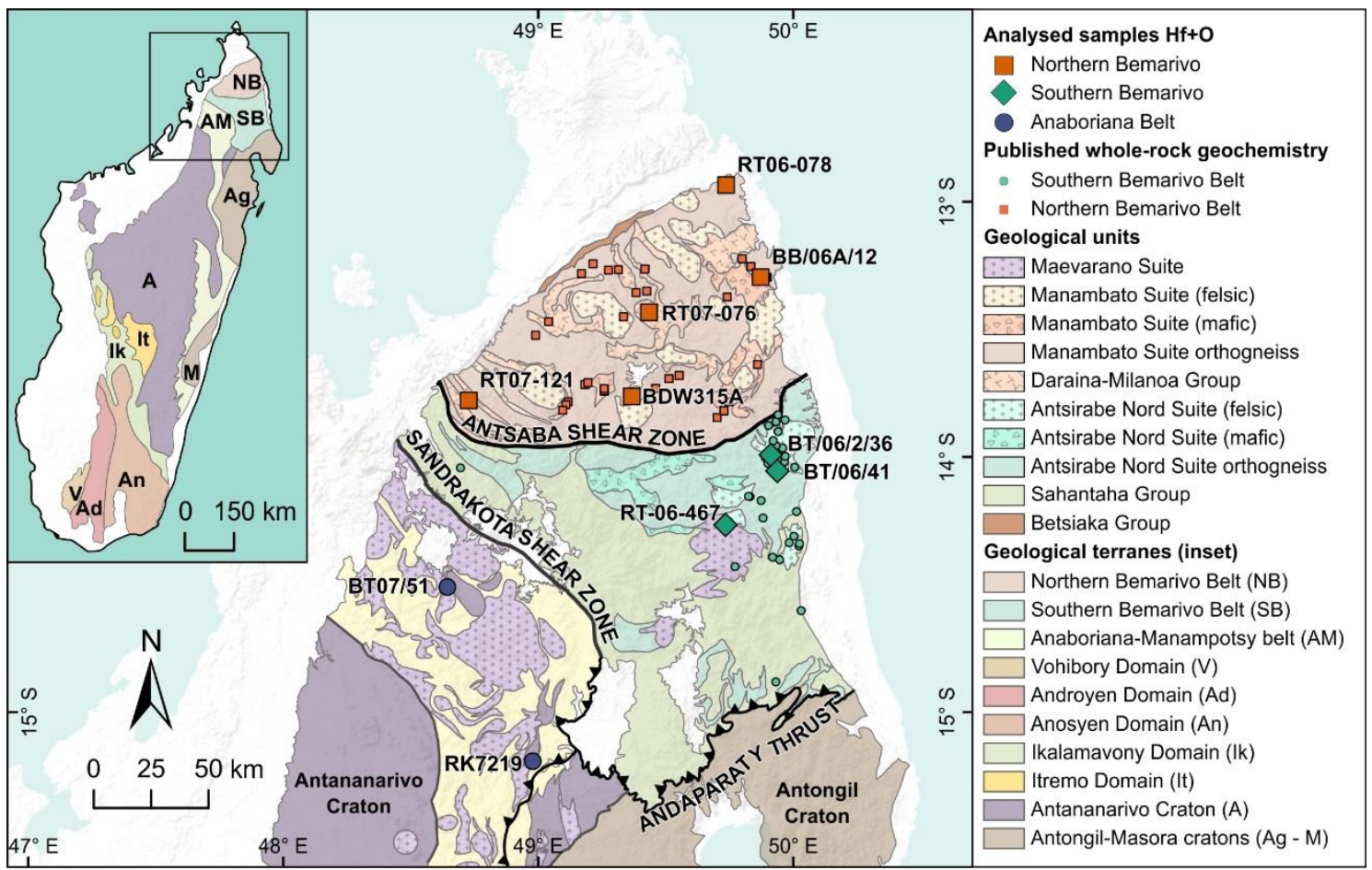

Figure 1 Geological map of northern Madagascar modified to reflect our interpretation of the region.

Modified from Roig et al. (2012) and Thomas et al. (2009), inset modified from De Waele et al. (2011).

\section{Methodology}

Zircon grains were selected from those analysed for $\mathrm{U}-\mathrm{Pb}$ through the Madagascar World Bank Project (BGS-USGS-GLW, 2008). Ten samples that cover a broad area in northern Madagascar were selected for $\mathrm{Hf}$ and $\mathrm{O}$ analysis to characterise the isotopic nature of this region (Figure 1). Detailed methodologies are provided in Supplementary file A and isotopic data are provided in Supplementary file B. Zircon $\mathrm{U}-\mathrm{Pb}$ data were collected using the SHRIMP instrument at the John de Laeter Research Centre at Curtin University (BGS-USGS-GLW, 2008; Thomas et al., 2009). We have reinterpreted weighted averages from these data for consistency and these are summarised in Table 1.

\section{Zircon $\mathrm{U}-\mathrm{Pb}$, $\mathrm{Hf}$ and $\mathrm{O}$ isotope data}

\section{$141 \quad 3.1 \quad$ Anaboriana Belt}

142 Two gneiss samples (BT0751 and RK7219) analysed from the Anaboriana Belt have

143 ambiguous protoliths and it is unclear if they are derived from magmatic or sedimentary

144 protoliths (BGS-USGS-GLW, 2008). U-Pb geochronology was unable to resolve this as there is considerable scatter on concordia plots for both samples, which could be either lead loss due to metamorphism or a detrital array. ${ }^{176} \mathrm{Hf} /{ }^{177} \mathrm{Hf}_{\mathrm{i}}$ values obtained for these samples are 
consistent with lead loss and age resetting for the zircon grains as the values plot in a horizontal array (within uncertainty) across an age vs. ${ }^{176} \mathrm{Hf} /{ }^{177} \mathrm{Hf}_{\mathrm{i}}$ plot. Although the $\mathrm{Hf}$ isotope data are not conclusive, a magmatic protolith is also supported by the $\mathrm{O}$ isotope values. Analyses from the two samples have $\delta^{18} \mathrm{O}$ values between $+1.3 \%$ and $+4.4 \%$. These values are below values normally expected for crustal or mantle values and are typically associated with the involvement of meteoric waters being involved in hydrothermal alteration of volcanic/sub-volcanic magma systems (e.g.Bindeman and Valley, 2001; Valley et al., 1998). It is highly unlikely that anomalous values such as these could be recorded in every single magma system that contributed detritus to a sedimentary rocks, and hence the samples are considered to have igneous protoliths-potentially volcanic or upper crustal intrusives.

Calculated magmatic crystallisation ages for samples RK7219 and BT0751 are $750 \pm 4$ Ma and $768 \pm 8 \mathrm{Ma}(2 \sigma)$ respectively (Table 1 ). When calculated at these ages (to remove the effects of $\mathrm{Pb}-\mathrm{loss}), \varepsilon_{\mathrm{Hf}}(\mathrm{t})$ values for magmatic zircons are in the range -3.4 to -10.1 . Four $\mathrm{U}-\mathrm{Pb}$ rim analyses from sample RK7219 yield a calculated age of $514 \pm 6$ Ma and seven analyses from sample BT0751 yield an age of $518 \pm 4 \mathrm{Ma}$, which we interpret as the age of metamorphism.

\subsection{Southern Bemarivo}

Three samples were analysed from the southern Bemarivo Belt. These rocks include, granodioritic gneiss, tonalitic gneiss and diorite (Table 1). Interpreted magmatic crystallisation ages for these rocks range from c. 756 Ma to c. $746 \mathrm{Ma}$ (Figure 2). Lu-Hf analyses from samples BT0636, BT0641 and RT06467 have negative $\varepsilon_{\mathrm{Hf}}(\mathrm{t})$ values ranging from -15.0 to -1.5 (Figure 3). These analyses have two-stage depleted mantle model ages spanning c. 2.6-1.7 Ga.

Oxygen isotope data from the southern Bemarivo Belt show a wide range of $\delta^{18} \mathrm{O}$ values. The majority of analyses from samples BT0641 and BT0636 are between $+4.8 \%$ and $+5.9 \%$, overlapping with the range of values expected for mantle-derived zircons, but extending to more positive values consistent with samples that have crystallised in equilibrium with surface-derived water (Valley et al., 1998). Four analyses from sample BT0641 and two analyses from sample BT0636 have $\delta^{18} \mathrm{O}$ values lower than what is expected for mantle sources, ranging from $+0.6 \%$ to $+4.3 \%$. The majority of analyses from sample RT06467 are between $+6.3 \%$ and $+7.1 \%$, with two analyses of $+5.8 \%$ o that overlap with the mantle $\delta^{18} \mathrm{O}$ field. 


\subsection{Northern Bemarivo}

179 Five samples from the northern Bemarivo Belt were used for $\mathrm{Hf}$ and $\mathrm{O}$ isotopic analysis on

180 zircon. These rocks include, granites, granodioritic gneisses and rhyolites (Table 1). Magmatic crystallisation ages for these samples are younger than for the southern Bemarivo Belt and range from c. $740 \mathrm{Ma}$ to c. $705 \mathrm{Ma}$. Lu-Hf analyses from northern Bemarivo samples cluster to form a group of similar $\varepsilon_{\mathrm{Hf}}(\mathrm{t})$ signature and age. These analyses have positive $\varepsilon_{\mathrm{Hf}}(\mathrm{t})$ values between +4 and +11 and depleted mantle model ages spanning c. 1.4-1.0 Ga (Figure 3).

185 Samples from the northern Bemarivo Belt preserve a restricted range of $\delta^{18} \mathrm{O}$ values. Analyses 186 from samples RT0776, RT07121 and BDW315A have $\delta^{18} \mathrm{O}$ values ranging from $+4.4 \%$ o to

$187+6.5 \%$ (Figure 3). These overlap with the range of values typical for mantle-derived zircons

188 (5.3 $\pm 0.6 \%$; Valley et al. (1998)). Samples BB06A12 and RT06-78 have lower $\delta^{18} \mathrm{O}$ values, with mean $\delta^{18} \mathrm{O}$ values of $+4.3 \%$ and $+2.3 \%$ respectively. 

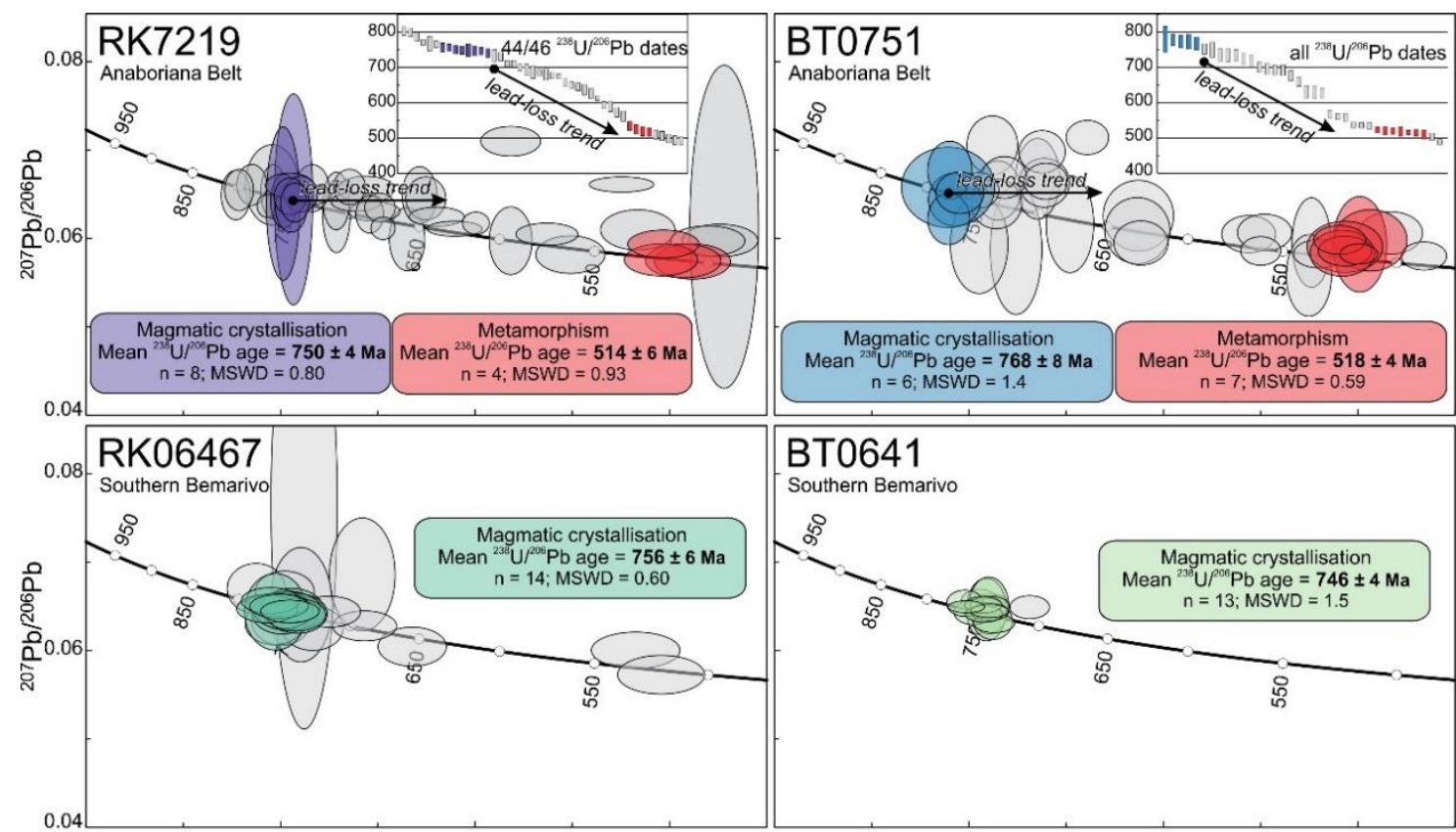

\section{BT0641 \\ Southern Bemarivo}
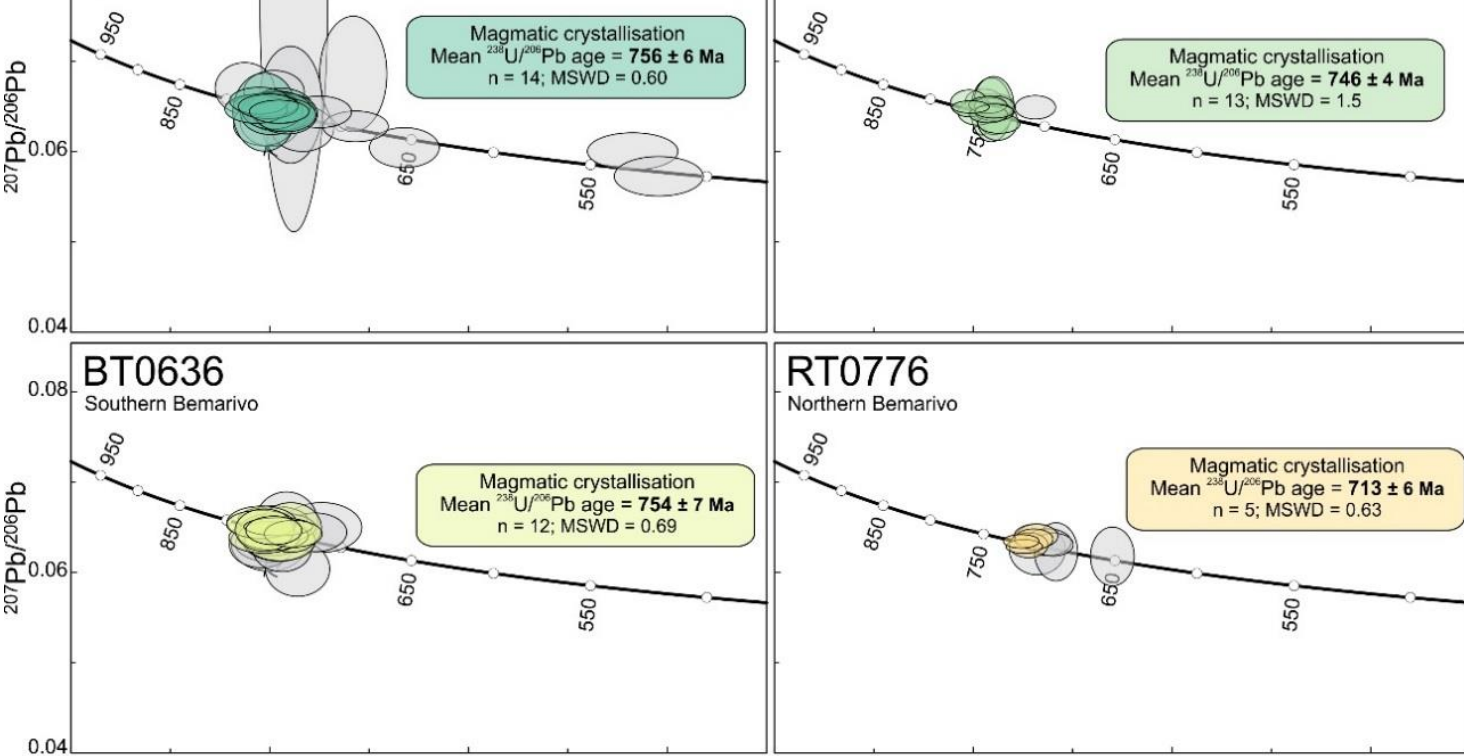

\section{RT0776}

Northern Bemarivo
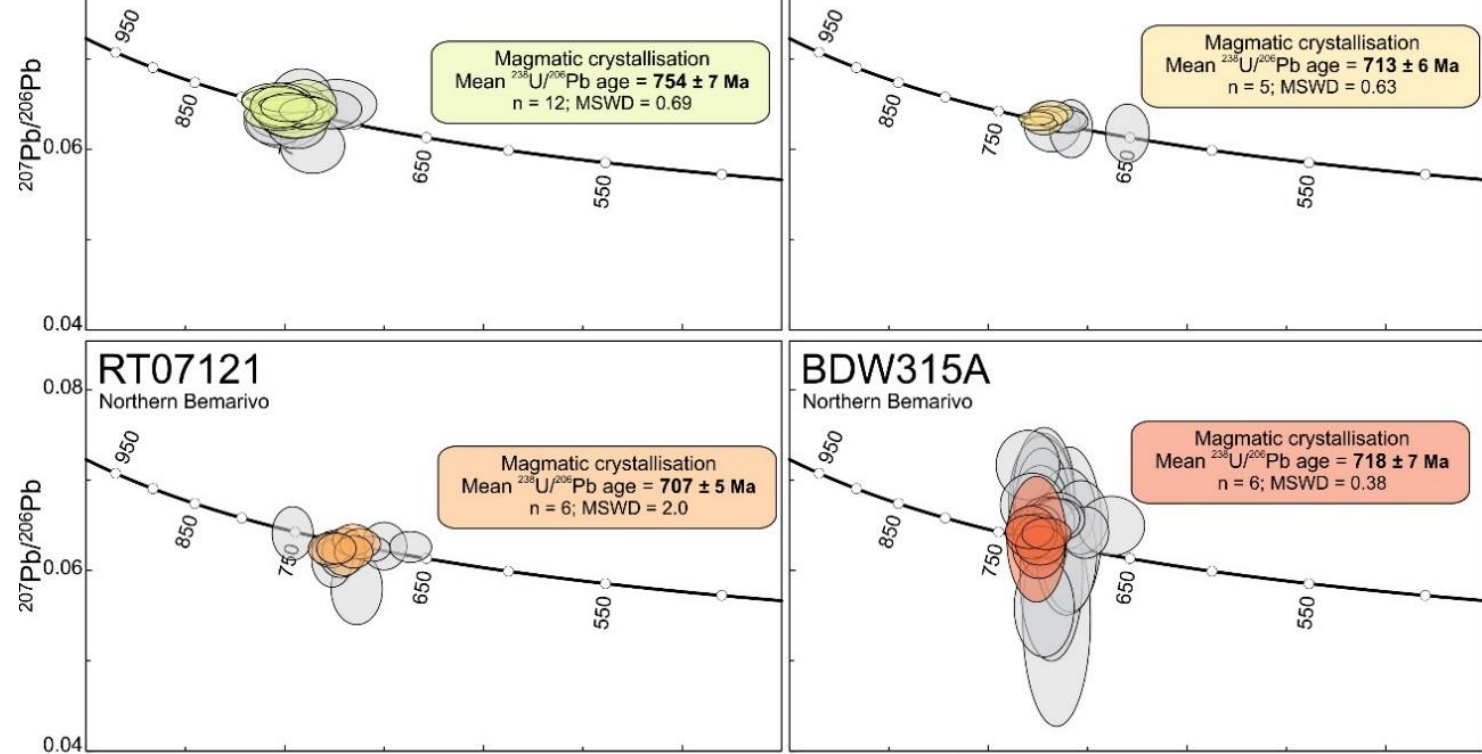

\section{BDW315A}
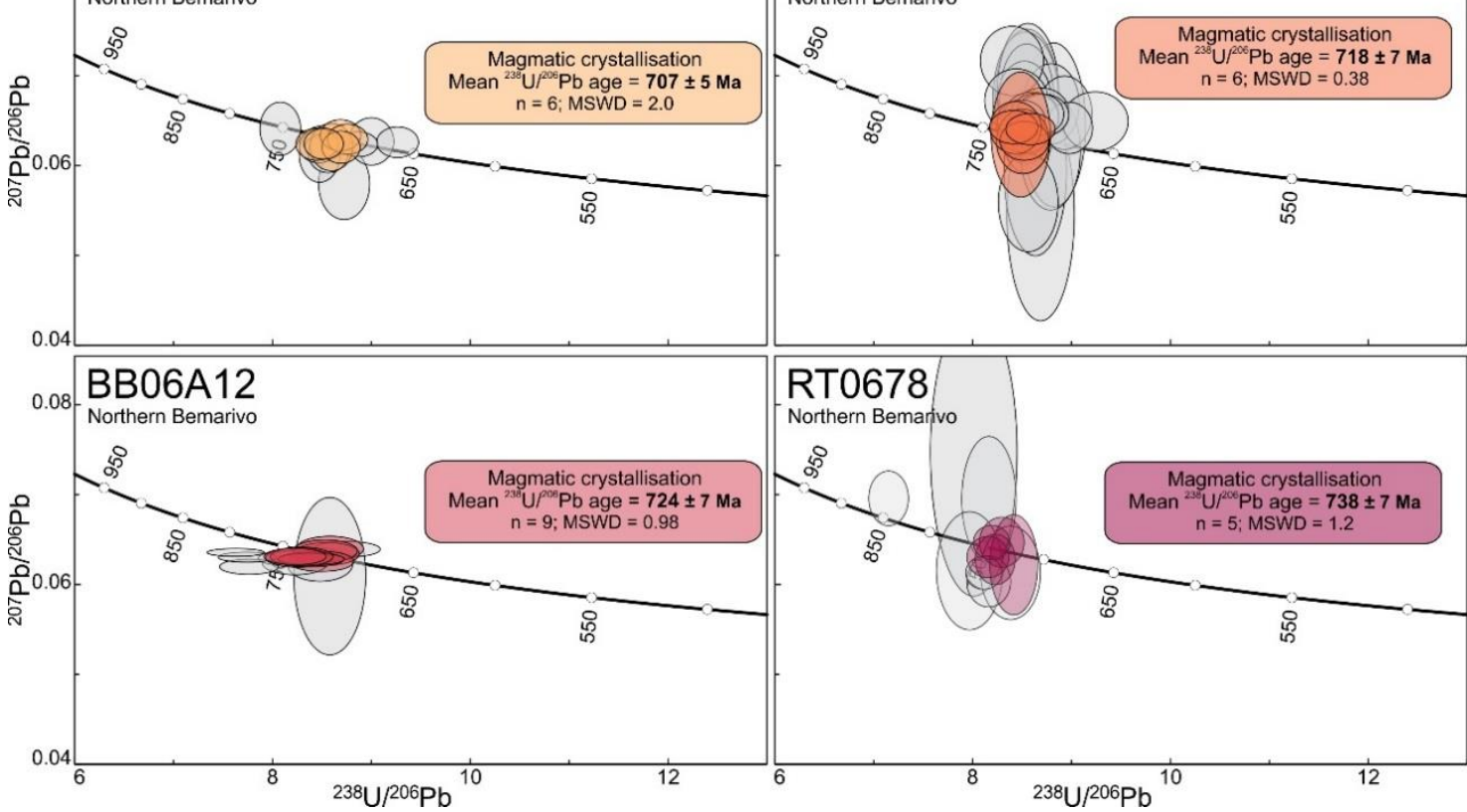

Figure 2 Concordia plots with reinterpreted ages using data from Thomas et al. (2009). Axes are the same range for all plots. Coloured ellipses were used to calculate the ages provided, grey ellipses show remaining data that were excluded from calculations. 

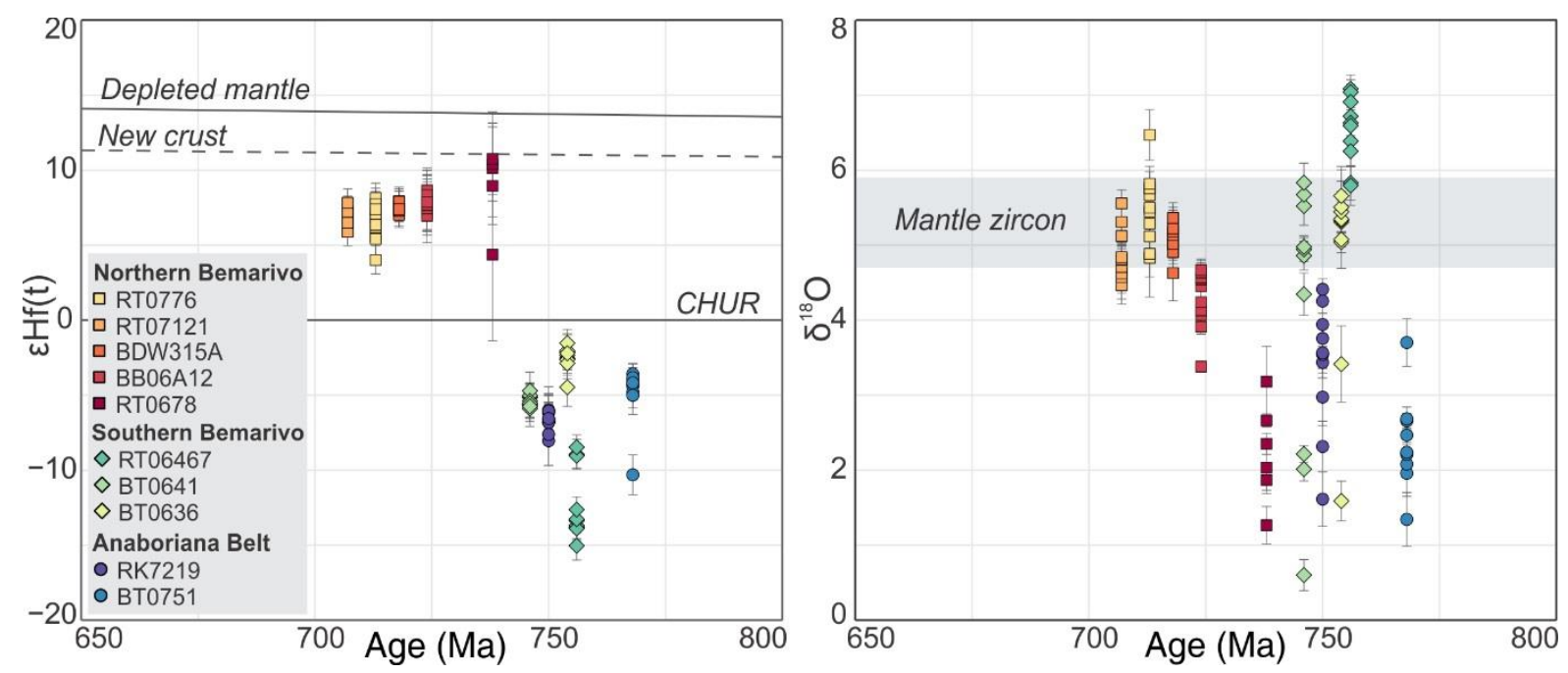

Figure $3 \varepsilon_{\mathrm{Hf}}(\mathrm{t})$ vs Age and $\delta^{18} \mathrm{O}$ vs Age (calculated ${ }^{238} \mathrm{U} /{ }^{206} \mathrm{~Pb}$ magmatic crystallisation ages) for samples analysed from northern Madagascar. $\varepsilon_{\mathrm{Hf}}(\mathrm{t})$ for each analysis was calculated using the magmatic crystallisation age, data given in Supplementary file B. Plots produced in $\mathrm{R}$, code written to produce plots is documented in supplementary file $\mathrm{C}$.

\section{Insights from published whole-rock geochemistry data}

Whole-rock geochemistry from the northern and southern Bemarivo Belt was published in Thomas et al. (2009). We have used these data to further compare and contrast the northern and southern Bemarivo Belts. We have shown that magmatic rocks from the southern Bemarivo Belt have evolved $\varepsilon_{\mathrm{Hf}}(\mathrm{t})$ signatures, so the geochemistry is potentially more reflective of the crust that's being incorporated rather than the processes that generated the mantle melts. Although there are only three samples that have both Hf isotope and whole-rock geochemistry data for the southern Bemarivo Belt, there does appear to be a trend between these two datasets. There more evolved sample has a more ferroan signature than the less evolved sample, which has a magnesian signature (Figure 4a). There is an increase in alkalinity for increasing $\varepsilon_{\mathrm{Hf}}(\mathrm{t})$ values (Figure $4 \mathrm{~b}$ ). The $\mathrm{Sr}$ anomalies and trace elements are also higher for the more evolved samples (Figure $4 \mathrm{~d}$, e). Together, this suggests that crustal assimilation was the dominant cause for changing $\varepsilon_{\mathrm{Hf}}(\mathrm{t})$.

In contrast, samples from the northern Bemarivo Belt are dominantly magnesian (Figure 4a), calc-alkalic (Figure 4b), and are not as enriched in trace elements (Figure 4e). Combined with the juvenile nature of the these rocks, we suggest they most likely formed in an arc environment, consistent with the interpretation of Thomas et al. (2009). Although there are only two samples with both Hf isotope and geochemistry data, the younger, slightly more evolved sample has a higher $\mathrm{Sr}$ anomaly and higher values for the majority of the trace elements (Figure 4c, d). This suggests that low degrees of fractionation and crustal 

accounts for the trend of decreasing $\varepsilon_{\mathrm{Hf}}(\mathrm{t})$ values with time (Figure 3$)$.
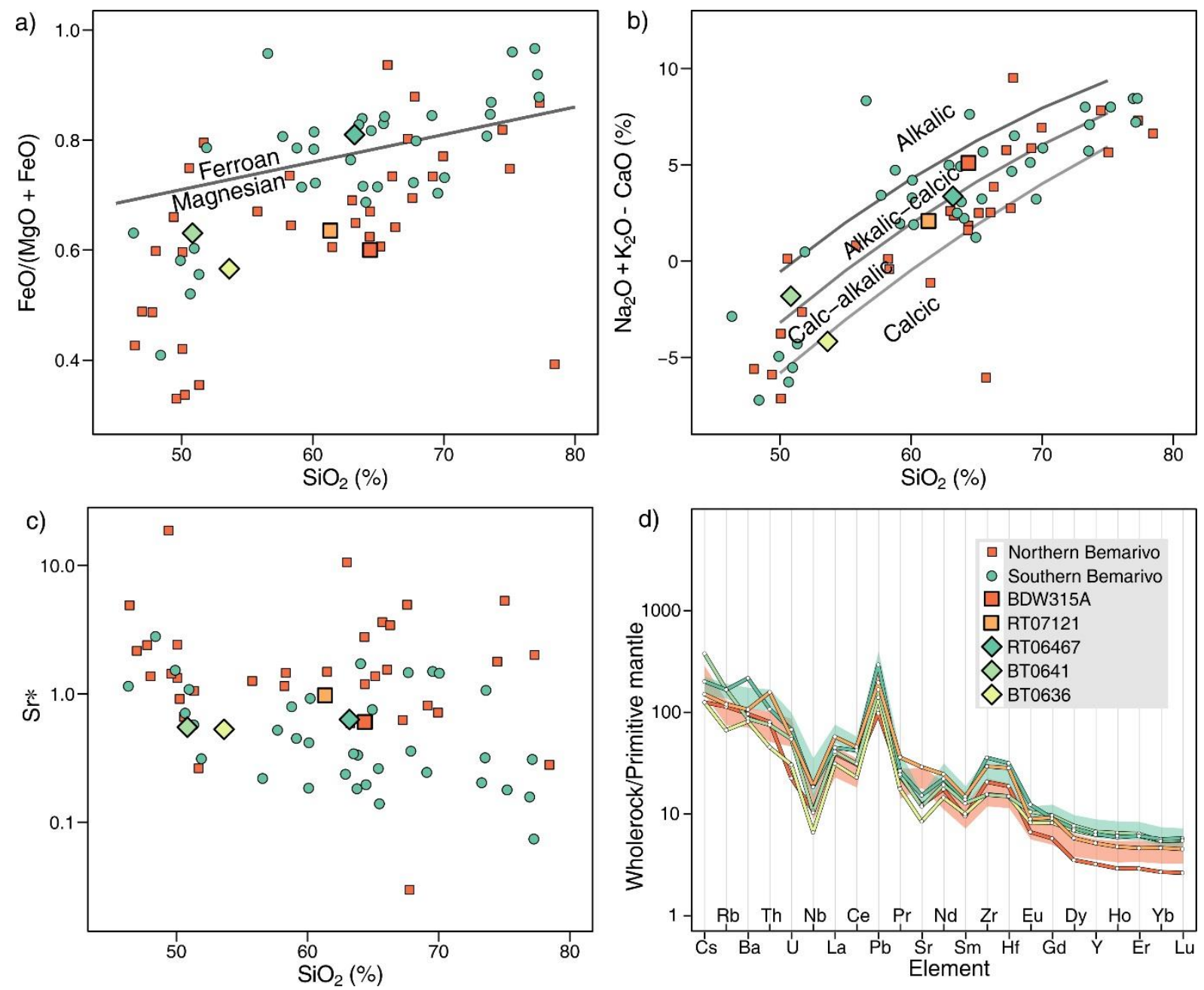

Figure 4 a) Fields for ferroan and magnesian rocks after Frost and Frost (2008); b) fields for alkali, alkali-calcic,

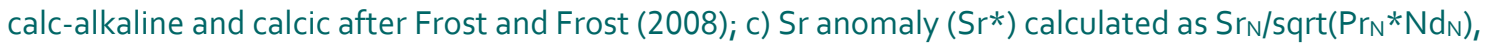
where $N$ is the chondrite normalised values after Sun and McDonough (1989); and d) Spider plot for samples with $\mathrm{Hf}$ and $\mathrm{O}$ isotope data. The shaded bands behind these lines are the bootstrapped mean and $95 \%$ confidence intervals of Primitive Mantle normalised elemental data for all samples from the northern and southern Bemarivo belts; normalising values from Sun and McDonough (1989). Bootstrapping was performed with replacement for 50000 repetitions. R scripts to produce plots are provided in supplementary file C. Data from Thomas et al. (2009).

\section{Regional evolution of the Bemarivo Belt}

The Bemarivo Belt of northern Madagascar has previously been interpreted as a juvenile Neoproterozoic arc-related terrane that amalgamated with the central Madagascar craton in the late Neoproterozoic to early Cambrian (Collins, 2006; Kröner et al., 2000; Tucker et al., 1999a). Possible genetic links between Madagascar and the Seychelles, Malani Igneous Suite of northwest India and south China have been proposed (Ashwal et al., 2002; Tucker et al., 
1999a; Wang et al., 2017). New Hf and O isotope data collected in this study allow us to interpret the tectonic evolution of the Bemarivo Belt and assess possible paleogeographical links. Distinct differences between these terranes indicate that they have undergone different tectonic histories at different times during the Neoproterozoic.

\subsection{Anaboriana Belt}

Zircons analysed from the two Anaboriana Belt samples have evolved $\varepsilon_{\mathrm{Hf}}(\mathrm{t})$ signatures that overlap with values from southern Bemarivo Belt samples, but are generally less evolved than those from the slightly older Imorona-Itsindro Suite (Archibald et al., 2016; Zhou et al., 2018). We interpret this evolved signature as the result of incorporation of crustal material during magma genesis. $\delta^{18} \mathrm{O}$ values for the Anaboriana Belt samples are lower than most analyses from the southern Bemarivo Belt. Low $\delta^{18} \mathrm{O}$ values are typically the result of hydrothermal cycling of meteoric water during magma generation (Bindeman and Valley, 2001; Valley et al., 1998). These are often correlated with extensional environments where rifting may have occurred that facilitated hydrothermal circulation in near-surface or volcanic settings (Bindeman and Valley, 2001; Valley et al., 1998). We therefore suggest that the Anaboriana Belt samples were generated from magmas that contained a component of older crustal material, but likely underwent hydrothermal alteration in an extensional environment.

\subsection{Southern Bemarivo Belt}

The southern Bemarivo Belt samples contain zircons with negative $\varepsilon_{\mathrm{Hf}}(\mathrm{t})$ signatures that suggest a contribution of continental crust during magma generation. $\varepsilon_{\mathrm{Hf}}(\mathrm{t})$ model ages for these analyses range between c. 2.56-1.73 Ga. The majority of $\delta^{18} \mathrm{O}$ analyses from sample BT06467 are above the mantle range, indicating that supra-crustal rock assimilation and melting were involved in magma generation. The majority of zircon analyses from samples BT0641 and BT0636 have $\delta^{18} \mathrm{O}$ values in the mantle range. Several analyses from the aforementioned samples, as well as analyses from the Anaboriana Belt samples RK7219 and BT0751, have very low $\delta^{18} \mathrm{O}$ values that suggest the involvement of meteoric fluids and hydrothermal alteration in a similar way to that envisaged for similar values from the Tonian Imorona-Itsindro Suite in central Madagascar by Archibald et al. (2016).

The Sahantaha Group in which these magmatic rocks intrude, have major detrital zircon components of c. 2500-1700 Ma (De Waele et al., 2011), broadly overlapping with the range of depleted mantle model ages for the analysed samples. The Antananarivo Domain, which may underlie the Sahantaha Group, is dominantly comprised of c. 2500 Ma gneisses. The data presented here support the interpretation of Thomas et al. (2009) that subduction was taking 
place beneath the Sahantaha Group (and underlying Antananarivo Domain) at c. 750 Ma, which produced melts that incorporated crustal material from surrounding rocks. This interpretation is consistent with previous models for the southern Bemarivo Belt (Thomas et al., 2009). Low $\delta^{18} \mathrm{O}$ samples from the Anaboriana Belt may have formed in a back-arc extensional environment to the main southern Bemarivo volcanic arc.

\subsection{Northern Bemarivo Belt}

Samples analysed from the northern Bemarivo Belt are dominated by relatively juvenile $\varepsilon_{\mathrm{Hf}}(\mathrm{t})$ signatures, and $\delta^{18} \mathrm{O}$ values that suggest a mantle source and relatively little assimilation of supra-crustal material. The majority of analyses from samples RT0776, RT07121 and BDW315A have $\delta^{18} \mathrm{O}$ values in the mantle range, but samples BDW315A and RT0678 have $\delta^{18} \mathrm{O}$ values that are significantly lower than those from the mantle. Given the similar $\varepsilon_{\mathrm{Hf}}(\mathrm{t})$ values of these samples and the other northern Bemarivo Belt samples, we suggest that they were also generated from a juvenile depleted mantle source but involved hydrothermal fluids during magma generation. This may relate to their generation in an extensional environment (Bindeman and Valley, 2001; Valley et al., 1998). The felsic nature of the northern Bemarivo Belt suggests that the original magmas were likely to have fractionated in thickened crust. The juvenile Hf signatures of these samples, and mantle-like $\delta^{18} \mathrm{O}$ values, suggest that they formed in an arc environment, with little involvement of any significantly older, or supra-crustal material.

Our new Hf and O data from northern Madagascar indicate that the northern Bemarivo Belt and the southern Bemarivo Belt have very different isotopic evolutions and we therefore suggest that they were not contiguous at the time of their formation (c. $750 \mathrm{Ma}$ ). The Antsaba Shear Zone that marks the boundary between the northern and southern Bemarivo Belt (Thomas et al., 2009), also marks a boundary between samples of a juvenile signature in the north, and an evolved signature in the south. We therefore suggest that the Antsaba Shear Zone marks a major tectonic boundary in northern Madagascar and likely represents a cryptic suture zone.

\section{Assembly of north Malagasy Gondwana}

\subsection{Models for the assembly of northern Madagascar}

The terranes of northern Madagascar form a tectonically confusing triple-junction (Figure 1), with the southern Bemarivo Belt (including the Sahantaha Group), Anaboriana Belt and Antongil Domain all in contact with each other (Figure 1). We have shown here that rocks 
from the Anaboriana Belt and southern Bemarivo Belt are isotopically similar, and we suggest that they were part of the same continental-margin volcanic arc system at c. $750 \mathrm{Ma}$. The relationship between these two terranes and the Antongil Domain, is less straightforward. Understanding the nature and timing of contacts between these three terranes is essential for understanding the evolution of northern Madagascar.

\subsection{The amalgamation of the Dharwar Craton with Madagascar}

The assembly of northern Madagascar is a contentious topic with different models proposed for the nature and timing of amalgamation (e.g. Armistead et al., 2017; Boger et al., 2014; Collins and Windley, 2002; Tucker et al., 2011). The relationship between the Sahantaha Group (maximum depositional age c. $1600 \mathrm{Ma}$, minimum depositional age c. $800 \mathrm{Ma}$ ) and the Antongil Craton provides clues as to the relative timing of these tectonic events. Despite the current fault contact marked by the major Andaparaty Thrust between the Sahantaha Group and Antongil Domain (Figure 1), several authors have suggested that the Sahantaha Group stratigraphically overlies the Antongil Domain (Bauer et al., 2011; De Waele et al., 2011), implying that the Antongil Domain must have been adjacent to central Madagascar at the time of deposition. Against this interpretation are the paucity of c. 3100 Ma detrital zircons in the Sahantaha Group (De Waele et al., 2008; Thomas et al., 2009), despite the Antongil Craton being rich in zircon-bearing protoliths of this age (Tucker et al., 1999b) and the lack of any depositional contact mapped between the terranes. We suggest that these observations support that the Sahantaha Group is allochthonous with respect to the Antongil Craton and that the two were juxtaposed by the major Andaparaty Thrust.

If these two terranes did form separately from each other, when did they come together? Widespread metamorphism throughout much of northern Madagascar is recorded at c. 530510 Ma (Buchwaldt et al., 2003; Jöns et al., 2009), and we suggest that this event records the amalgamation of the Antongil Craton with the rest of Madagascar (including the Sahantaha Group and Anaboriana Belt), along the Betsimisaraka Suture of Collins and Windley (2002).

\subsection{What does the Anaboriana Belt represent?}

The Anaboriana-Manampotsy belt (Fig 1) has been interpreted to mark the approximate location of the Betsimisaraka Suture that has been interpreted as the site of amalgamation of the Antananarivo Craton with the Dharwar Craton (at the time including the Antongil-Masora domains) during the Ediacaran to early Cambrian (Armistead et al., 2017; Collins et al., 2003a; Collins and Windley, 2002). The Anaboriana Belt is the northern part of this extensive belt and separates the Sahantaha Group from the Antananarivo Craton. Above, we've argued that 
the Sahantaha Group formed stratigraphically above the Antananarivo Craton, which implies that the Anaboriana Belt is not a suture, or at least would only have been a minor marginal Neoproterozoic ocean basin suture. An alternative interpretation for the AnaborianaManampotsy belt is that it does not represent a suture zone but was an elongated sedimentary basin that formed due to Tonian rifting (Tucker et al., 2011).

As we have described in our interpretation of samples from the Anaboriana Belt, due to pervasive high-grade metamorphism, it can be difficult to recognise sample protoliths as either sedimentary or magmatic in origin. It is therefore unclear whether the Anaboriana Belt represents a sedimentary sequence at all, or whether it should really be considered as a zone of major high-strain shearing. To date, samples from the entire length of the Anaboriana Belt have been interpreted with protolith ages ranging from c. $850 \mathrm{Ma}$ to c. $750 \mathrm{Ma}$, with metamorphism interpreted from zircon rims at c. 550-520 Ma. Given the similarities in age and Hf isotope signatures between the Anaboriana Belt and the southern Bemarivo Belt, we suggest that the Anaboriana Belt was originally a c. 850-750 Ma group of rocks much like the southern Bemarivo Belt (and probably Imorona-Itsindro Suite) that were sheared and metamorphosed at c. $520 \mathrm{Ma}$, coinciding with emplacement of the age-equivalent Maevarano Suite. The more definitive metasedimentary rocks of the Manampotsy Belt to the south do demonstrate the presence of a Neoproterozoic basin in this area (Collins et al., 2003b). We suggest that this represents the Betsimisaraka Suture, but as it trends north, it becomes the Andaparaty Thrust, striking easterly into sea, and looping back on land as the Antsaba Shear Zone (Figure 1).

\subsection{Final assembly of northern Madagascar}

The c. 537-522 Ma Maevarano Suite (Goodenough et al., 2010) was previously interpreted to represent a maximum age constraint on the assembly of the Bemarivo Belt with the central Madagascar craton (Thomas et al., 2009). However, this was based on the premise that the Maevarano Suite intrusions were pervasive right throughout Madagascar-including the Bemarivo Belt-with the exception of the Antongil Craton. We have shown here that the northern and southern Bemarivo belts should be considered as two distinct terranes based on $\mathrm{Hf}$ and $\mathrm{O}$ isotopic differences, and therefore any interpretation of the Bemarivo Belt should consider these terranes separately. Despite geological mapping of Maevarano Suite granites in the northern Bemarivo Belt (BGS-USGS-GLW, 2008; Goodenough et al., 2010; Thomas et al., 2009), there are no published geochronological data to suggest that age equivalent Maevarano Suite granites are exposed here. 
368 Similarly, the Maevarano Suite is not exposed in the Antongil Craton. The reasons given as to

369 why the Maevarano Suite does not crop out in the Antongil Craton were outlined by

370 Goodenough et al. (2010) and we suggest that these explanations are applicable to the

371 northern Bemarivo Belt. These are: 1) a suitable source was not present beneath these

372 terranes; and/or 2) structural controls led to the emplacement of magmas only in certain areas

373 (i.e. along shear zones). We suggest a third possibility for the northern Bemarivo Belt, where

374 this terrane may not have been accreted to Madagascar at the time of granite emplacement, or

375 that it was accreted in the very late stages of magmatism and therefore did not undergo the

376 same degree of crustal preconditioning. In any case, we suggest that the Maevarano Suite and

377 associated metamorphism, approximately marks the final assembly of northern Madagascar

378 into its current configuration.

a) c. $850-760 \mathrm{Ma}$
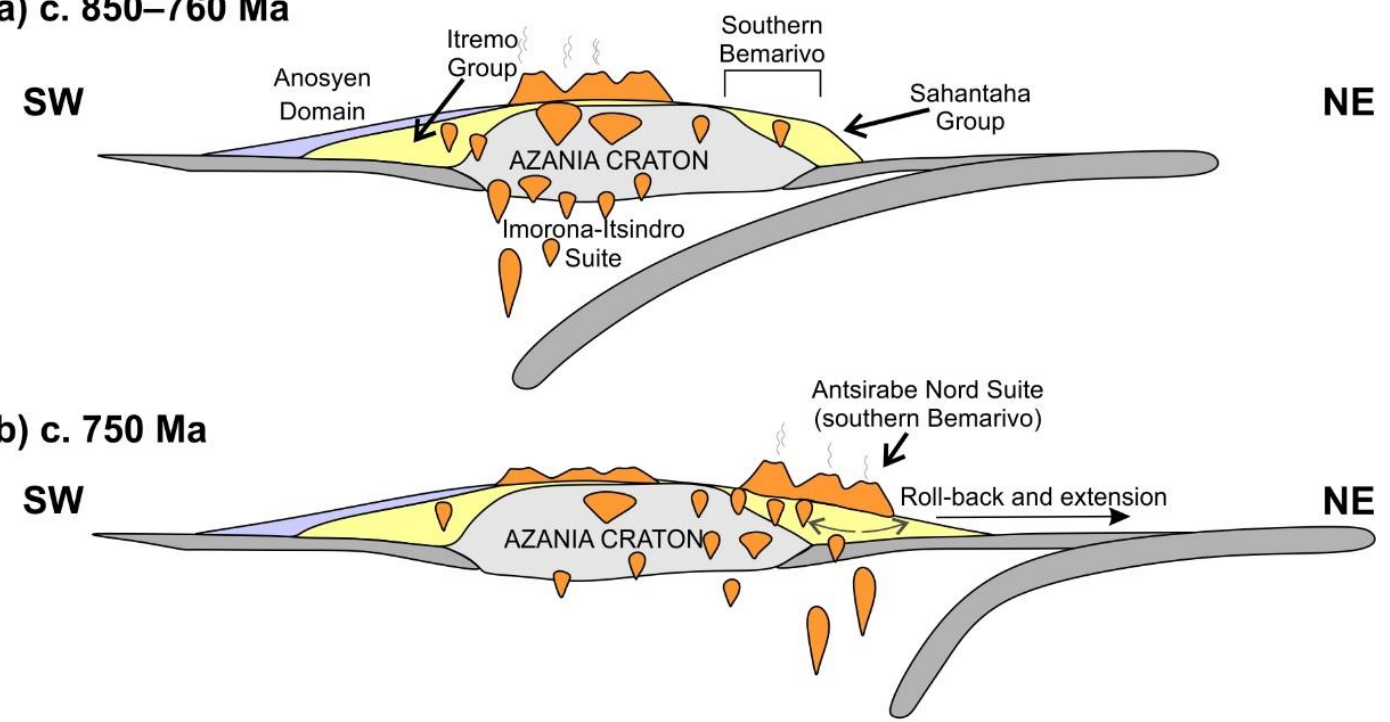

c) C. $550 \mathrm{Ma}$

Deformation of the

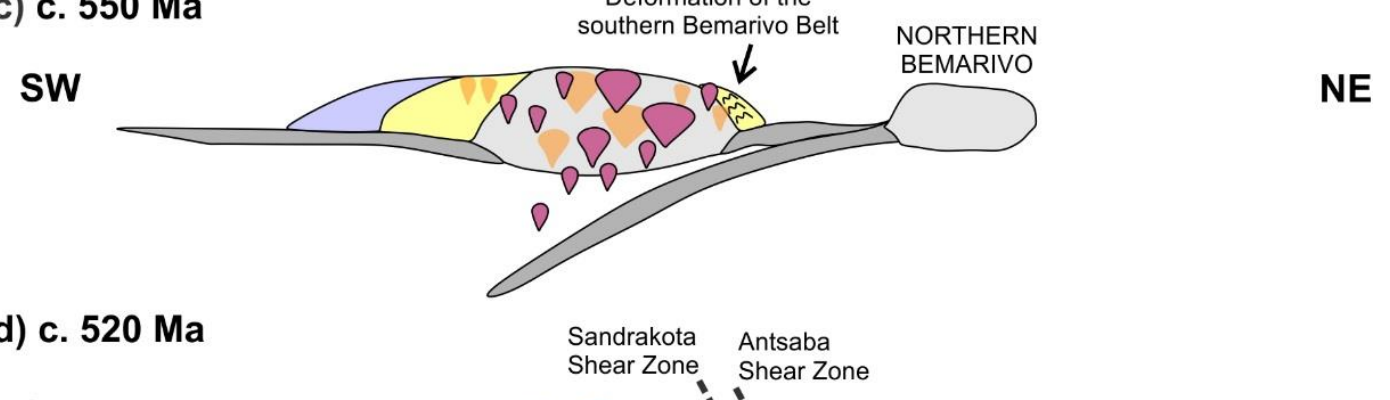

sw

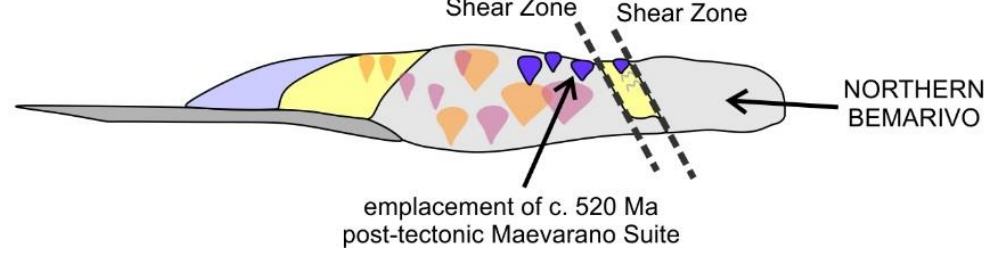

NE 
Figure 5 Schematic diagram of the Neoproterozoic arc evolution of Madagascar. Part a modified after Boger et al. (2014). Features outlined in black (e.g. magmatic suites and fold belts) are active at that time period, grey outlined features are already emplaced.

\section{Links to Rodinia}

In an attempt to link the northern Bemarivo Belt with other potential c. 720 Ma arc terranes, we have compared our new isotopic data from the northern Bemarivo Belt with several regions containing age equivalent rocks. We compared the northern Bemarivo Belt with South China, northwest India, central Madagascar, Seychelles, Israel and the Arabian Nubian Shield (Figure 6). We also integrated this dataset with the GPlates Neoproterozoic tectonic model (Merdith et al., 2017) to better assess correlations both temporally and spatially.

We have used a revised model of Merdith et al. (2017), which provides a framework for a global tectonic model during the Neoproterozoic. The benefit of using this model is that it takes into account paleogeographic constraints from other regions and integrates key datasets such as paleomagnetism, geochronology and geophysics to form a full-plate tectonic framework. We calculated an average age and average $\varepsilon_{\mathrm{Hf}}(\mathrm{t})$ for each sample compiled in our database. This dataset was then added to GPlates as a shapefile and a start and end time for each data point was assigned \pm 30 Ma (i.e. each point will show up 30 Ma before the average age and disappear $30 \mathrm{Ma}$ after). Data points are coloured according to their average $\varepsilon_{\mathrm{Hf}}(\mathrm{t})$ value.

It has been suggested that the Imorona-Itsindro Suite of central Madagascar is analogous to the Seychelles and the Malani Igneous Suite granitoids based on age correlations (Tucker et al., 2001; Tucker et al., 2014). Tectonic models by Wang et al. (2017) and Ashwal et al. (2013) proposed a continuous juvenile Andean-type arc between south China, the Malani Igneous Suite of northwest India and Seychelles. Wang et al. (2017) further included the ImoronaItsindro suite along with this magmatic arc. However, available $\varepsilon_{\mathrm{Hf}}(\mathrm{t})$ data from the ImoronaItsindro Suite of central Madagascar (Archibald et al., 2016; Zhou et al., 2018) is predominantly evolved (Figure 6), implying that it does not correlate with this juvenile arc system. Oman has also been interpreted as a series of arcs that accreted to Rajasthan in northwest India (which includes the Malani Igneous Suite) during the period c. 850-720 Ma (Blades et al., in review). We have shown here that age-equivalent rocks from the northern Bemarivo Belt, have juvenile $\varepsilon_{\mathrm{Hf}}(\mathrm{t})$ signatures, which correlate well with $\varepsilon_{\mathrm{Hf}}(\mathrm{t})$ data from the proposed south China-Malani-Seychelles arc system of Wang et al. (2017) as well as new data from Oman (Blades et al., in review) (Figure 6). These correlations are highlighted in the full- 
plate tectonic model in GPlates, where juvenile analyses (data points with shades of red; Figure 7) all form an elongated 'arc' along the western (reconstructed orientation) margin of India and China.

The period of arc magmatism in this proposed arc was long-lived, beginning at around c. 850 Ma and ending at around c. 700 Ma. There is a general southward younging trend (reconstructed orientation; Figure 7), with the oldest record coming from China, and progressing to younger rocks through Oman, Malani, Seychelles and the northern Bemarivo Belt. It is possible that this period of juvenile arc magmatism represents a single long-lived arc, however, we suggest that a complex history of accretionary terranes that formed along the edge of Rodinia, is more likely.

Samples analysed from the northern Bemarivo Belt are slightly younger than rocks from south China and Malani, although they have similar juvenile $\varepsilon_{\mathrm{Hf}}(\mathrm{t})$ signatures. It is therefore likely that the northern Bemarivo Belt formed during the late stages of this juvenile arc system, possibly on a rolled-back crustal remnant of south China, Malani or Oman-like crust. The whole-rock geochemistry data (Figure 4) suggest that the northern Bemarivo Belt underwent a degree of crustal assimilation and fractionation (see section 4). However, the $\varepsilon_{\mathrm{Hf}}(\mathrm{t})$ data suggest that the northern Bemarivo Belt is dominantly juvenile, with little input of significantly older crustal material. Together this suggests that the crustal assimilate incorporated into magmatic rocks of the northern Bemarivo Belt was not significantly older than c. 720 Ma. This supports a model where the northern Bemarivo Belt formed on a crustal remnant of slightly older crust, possibly from south China, Malani or Oman (Alessio et al., 2018). This accounts for the crustal assimilation signatures in whole-rock geochemistry, and relatively juvenile $\varepsilon_{\mathrm{Hf}}(\mathrm{t})$ signatures.

The integration of $\varepsilon_{\mathrm{Hf}}(\mathrm{t})$ data with the full-plate tectonic model of (Merdith et al., 2017) broadly supports the south China-Malani-Seychelles linkage proposed by Wang et al. (2017) and Ashwal et al. (2013), and the links between Oman and northwest India proposed by Blades et al. (in review). We further extend this model to include the northern Bemarivo Belt of northern Madagascar as a younger, more outboard component of this arc system. There is no significant overlap between the highly evolved data from the Imorona-Itsindro Suite and that of this proposed Neoproterozoic arc system. The lack of juvenile Hf data from the Imorona-Itsindro Suite suggests that this terrane was not part of the south China-MalaniSeychelles-Bemarivo arc, which is dominated by weakly evolved to juvenile rocks. 
Our proposal of linking these previously discrete volcanic arcs into a long-lived subduction zone can help elucidate long term trends in plate boundary length and, when compared to the connectedness of continental lithosphere, assist with quantitatively understanding the supercontinent cycle for pre-Pangea supercontinents (e.g. Merdith et al., in review). We have shown the power of integrating big isotopic data compilations into a plate tectonics framework to better understand the evolution of supercontinents through time.
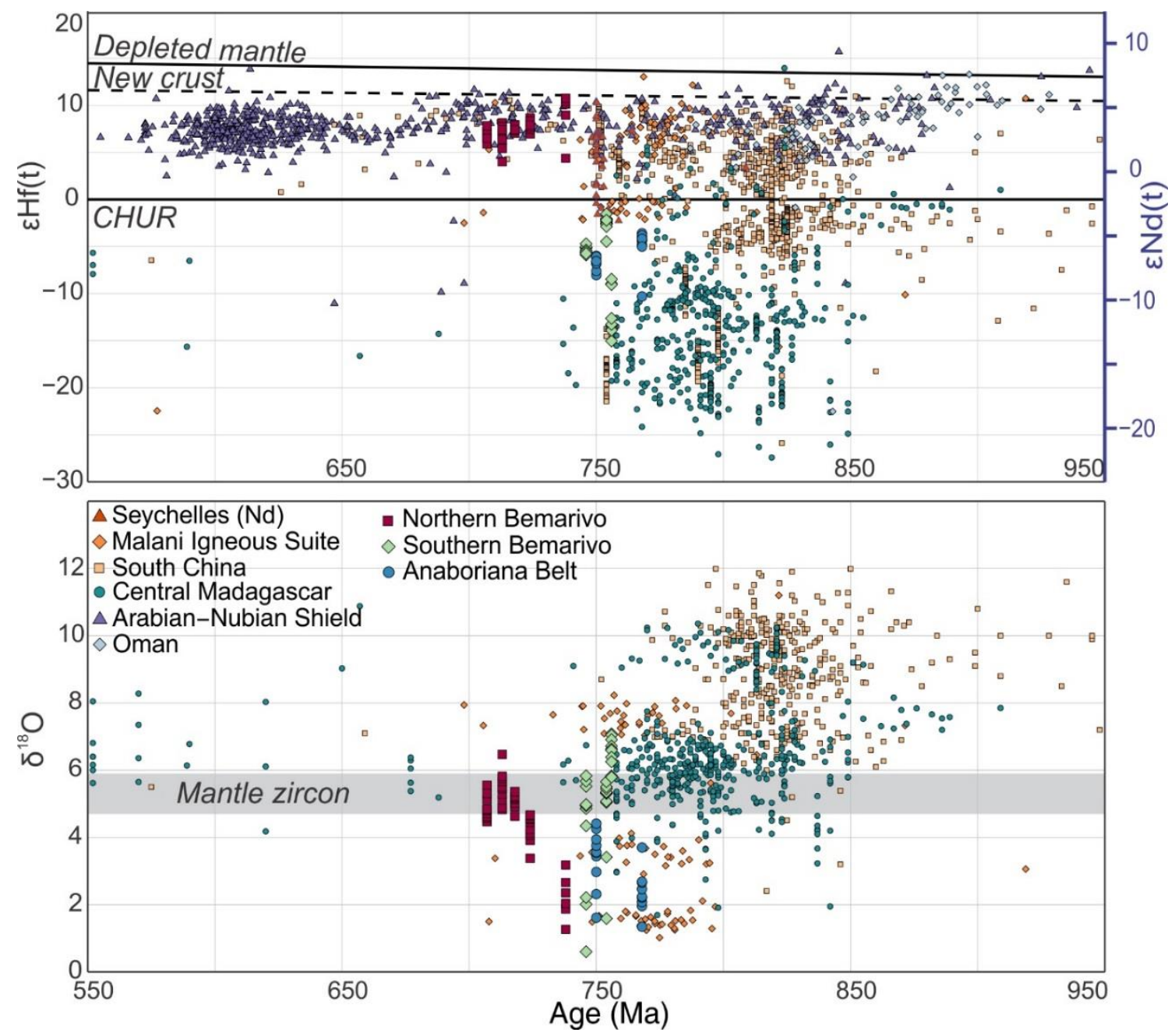
Figure $6 \varepsilon_{H f}(\mathrm{t})$ vs age and $\delta^{18} \mathrm{O}$ vs age for other regions compared to northern Madagascar; Seychelles data is converted from $\varepsilon_{\mathrm{Nd}}(\mathrm{t})$ to $\varepsilon_{\mathrm{Hf}}(\mathrm{t})$ using the equation $\varepsilon_{\mathrm{Hf}}(\mathrm{t})=1.34 \varepsilon \mathrm{Nd}(\mathrm{t})+2.95$ for 'terrestrial array' (Vervoort et al., 1999) and scale is shown to the right of the plot. $R$ scripts to produce plots are provided in supplementary file C. Data sourced from: Alessio et al. (2018); Archibald et al. (2016); Ashwal et al. (2002); Blades et al. (2015); Huang et al. (2008); Long et al. (2011); Morag et al. (2011); Qi et al. (2012); Robinson et al. (2014); Wang et al. (2017); Wang et al. (2013); Zhao et al. (2013); Zheng et al. (2008); Zheng et al. (2007); Zhou et al. (2018).

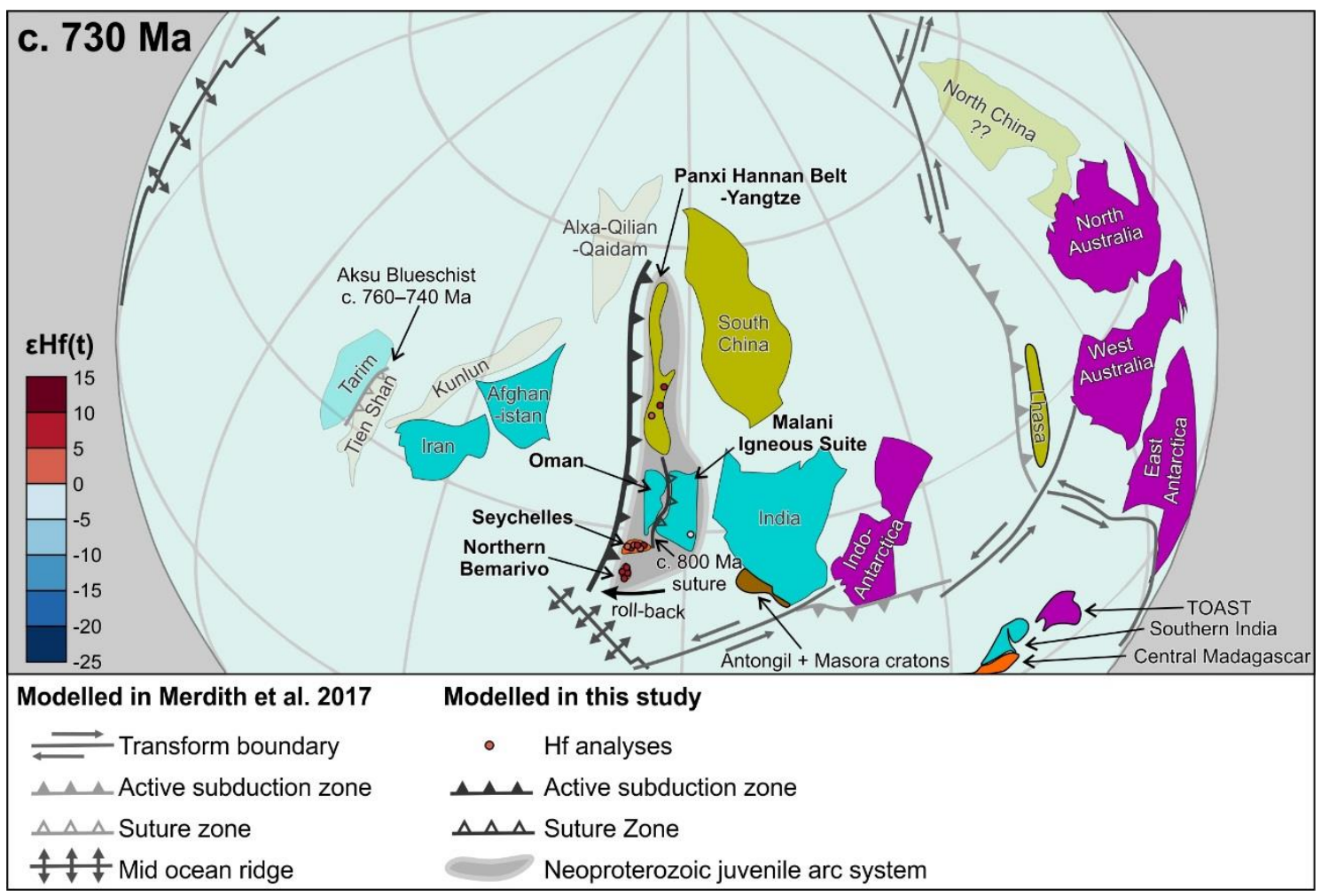

Figure 7 GPlates reconstruction at 730 Ma showing the location of compiled Hf and Nd isotope data (see Figure 6 for the conversion calculation used). Transparent polygons are uncertain in the model but are included as suggestions based on their positions post-Gondwana amalgamation. Lhasa is linked to Australia after Zhu et al. (2011), addition of the TOAST terrane to Azania after Jacobs et al. (2015) and Archibald et al. (2017a).

\section{Conclusions}

We have presented new zircon Hf and $\mathrm{O}$ isotope data that help unravel the subduction history of the Mozambique Ocean during the critical time of supercontinent cycle transition-from the Nuna/Rodinia cycle to the amalgamation of Gondwana. We have compared these Madagascar data to other age-equivalent terranes globally. The key outcomes of this research are:

1. The northern and southern Bemarivo belts are different terranes that have separate tectonic evolutions until the Cambrian, based on zircon $\varepsilon_{\mathrm{Hf}}(\mathrm{t})$ and $\delta^{18} \mathrm{O}$ data. 
2. The c. 750 Ma southern Bemarivo Belt and Anaboriana Belt are isotopically evolved terranes that may represent a younger component of the retreating volcanic arc represented in central Madagascar by the Imorona-Itsindro Suite.

3. The c. 720 Ma northern Bemarivo Belt is a juvenile terrane that we suggest formed in a juvenile arc environment related to the Seychelles, the Malani Igneous Suite of northwest India, Oman and the Yangtze Belt of South China. This is interpreted as formation above an aging, retreating, subduction zone.

4. The northern Bemarivo Belt collided with Madagascar at c. $520 \mathrm{Ma}$, after the main phase of orogenesis produced by the Betsimisaraka Suture.

\section{Acknowledgements}

Peter Holden is thanked for assistance with $\mathrm{O}$ isotope data collection and processing. The University of Adelaide TRaX research group are thanked for their continued support and collaboration. Raisa Lopes Costa is thanked for the use of a digitised geological map of Madagascar (fig 1). The British Geological Survey are thanked for the use of zircon mounts produced through the Madagascar World Bank Project. SA is funded by an Australian government PhD Scholarship and AC is funded by an Australian Research Council Future Fellowship FT120100340. This forms TRaX Record XX and is a contribution to IGCP projects 628 (Gondwana Map) and 648 (Supercontinent Cycles and Global Geodynamics). We thank the reviewers for their helpful feedback on this manuscript. 
Table 1: Summary of samples and U-Pb zircon geochronology used in this study. All ages are interpreted as magmatic crystallisation ages, except for those indicated by *

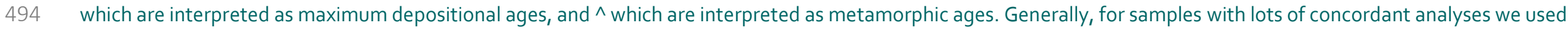
495 a cut-off of $\pm 5 \%$ concordance.

\begin{tabular}{|c|c|c|c|c|c|c|c|}
\hline Sample & $\begin{array}{l}\text { Longitud } \\
\text { e (WGS } \\
84 \text { ) }\end{array}$ & $\begin{array}{l}\text { Latitude } \\
\text { (WGS 84) }\end{array}$ & Region & $\begin{array}{l}\text { Stratigraphic unit or } \\
\text { domain }\end{array}$ & Rock description & $\begin{array}{l}{ }^{238} \mathrm{U} /{ }^{206} \mathrm{~Pb} \\
\text { Age }(\mathrm{Ma}) \pm \\
2 \sigma\end{array}$ & Calculation method \\
\hline RK7219 & 48.9828 & -15.1957 & $\begin{array}{l}\text { Anaboriana- } \\
\text { Manampotsy belt }\end{array}$ & $\begin{array}{l}\text { Groupe d'Androna- } \\
\text { Manampotsy }\end{array}$ & $\begin{array}{l}\text { Quartzofeldspathic } \\
\text { gneiss }\end{array}$ & $\begin{array}{l}750 \pm 4 \\
* 573 \pm 13 \\
\wedge 514 \pm 6\end{array}$ & $\begin{array}{l}\text { Weighted average of oldest near-concordant } \\
\text { analyses: } n=8, M S W D=0.80 \\
\text { *Youngest near-concordant (within } 5 \% \text { ) zircon core } \\
\text { analysis } \\
\wedge \text { Metamorphic age: } n=4, M S W D=0.93\end{array}$ \\
\hline BT0751 & 48.6479 & -14.5132 & $\begin{array}{l}\text { Anaboriana- } \\
\text { Manampotsy belt }\end{array}$ & $\begin{array}{l}\text { Group de Bealanana, } \\
\text { Anaboriana belt }\end{array}$ & Charnockite gneiss & $\begin{array}{l}768 \pm 8 \\
* 561 \pm 8 \\
\wedge 518 \pm 4\end{array}$ & $\begin{array}{l}\text { Weighted average of oldest near-concordant } \\
\text { analyses: } n=6, M S W D=1.4 \\
\text { *Youngest near-concordant (within } 5 \% \text { ) zircon core } \\
\text { analysis } \\
\wedge \text { Metamorphic age: } n=7, M S W D=0.59\end{array}$ \\
\hline RT06467 & 49.7379 & -14.2695 & $\begin{array}{l}\text { Southern Bemarivo } \\
\text { Domain }\end{array}$ & Bemarivo Domain & Granodioritic gneiss & $756 \pm 6$ & $n=14, M S W D=0.60$ \\
\hline BT0641 & 49.9411 & -14.0582 & $\begin{array}{l}\text { Southern Bemarivo } \\
\text { Domain }\end{array}$ & $\begin{array}{l}\text { Doany Arc, Bemarivo } \\
\text { Domain }\end{array}$ & Tonalitic orthogneiss & $746 \pm 4$ & $n=13, M S W D=1.5$ \\
\hline BT06_36 & 49.9153 & -13.9953 & $\begin{array}{l}\text { Southern Bemarivo } \\
\text { Domain }\end{array}$ & $\begin{array}{l}\text { Antsirabe-North Suite, } \\
\text { Douany arc, Bemarivo } \\
\text { Block }\end{array}$ & Diorite & $754 \pm 7$ & $n=12, M S W D=0.69$ \\
\hline RT0776 & 49.4385 & -13.4362 & $\begin{array}{l}\text { Northern Bemarivo } \\
\text { Domain }\end{array}$ & Bevoay Massif & Mica Granite & $713 \pm 6$ & $n=5, M S W D=0.63$ \\
\hline RT07121 & 48.7316 & -13.7815 & $\begin{array}{l}\text { Northern Bemarivo } \\
\text { Domain }\end{array}$ & Bemarivo Domain & $\begin{array}{l}\text { Metagranodiorite } \\
\text { gneiss }\end{array}$ & $707 \pm 5$ & $n=6, M S W D=2.0$ \\
\hline BDW315A & 49.3712 & -13.766 & $\begin{array}{l}\text { Northern Bemarivo } \\
\text { Domain }\end{array}$ & Bemarivo Domain & Metagranodiorite & $718 \pm 7$ & $n=6, M S W D=0.38$ \\
\hline BB06A12 & 49.8762 & -13.2988 & $\begin{array}{l}\text { Northern Bemarivo } \\
\text { Domain }\end{array}$ & Daraina Group & $\begin{array}{l}\text { Metarhyolite - flow } \\
\text { banded }\end{array}$ & $724 \pm 7$ & $n=9, M S W D=0.98$ \\
\hline RT0678 & 49.741 & -12.9375 & $\begin{array}{l}\text { Northern Bemarivo } \\
\text { Domain }\end{array}$ & Daraina Group & Rhyolite & $738 \pm 7$ & $n=5, M S W D=1.2$ \\
\hline
\end{tabular}


Alessio, B.L., Blades, M.L., Murray, G., Thorpe, B., Collins, A.S., Kelsey, D.E., Foden, J., Payne, J., Al-Khirbash, S. and Jourdan, F., 2018. Origin and tectonic evolution of the NE basement of Oman: a window into the Neoproterozoic accretionary growth of India? Geological Magazine, 155(5): 1150-1174.

Archibald, D.B., Collins, A.S., Foden, J.D., Payne, J.L., Holden, P., Razakamanana, T., De Waele, B., Thomas, R.J. and Pitfield, P.E.J., 2016. Genesis of the Tonian Imorona-Itsindro magmatic Suite in central Madagascar: Insights from U-Pb, oxygen and hafnium isotopes in zircon. Precambrian Research, 281: 312-337.

Archibald, D.B., Collins, A.S., Foden, J.D., Payne, J.L., Macey, P.H., Holden, P. and Razakamanana, T., 2017a. Stenian-Tonian arc magmatism in west-central Madagascar: the genesis of the Dabolava Suite. Journal of the Geological Society: jgs2017-028.

Archibald, D.B., Collins, A.S., Foden, J.D. and Razakamanana, T., 2017b. Tonian Arc Magmatism in Central Madagascar: The Petrogenesis of the Imorona-Itsindro Suite. The Journal of Geology, 125(3): 000-000.

Armistead, S.E., Collins, A.S., Payne, J.L., Foden, J.D., De Waele, B., Shaji, E. and Santosh, M., 2017. A re-evaluation of the Kumta Suture in western peninsular India and its extension into Madagascar. Journal of Asian Earth Sciences.

Ashwal, L., Demaiffe, D. and Torsvik, T., 2002. Petrogenesis of Neoproterozoic granitoids and related rocks from the Seychelles: the case for an Andean-type arc origin. Journal of Petrology, 43(1): 45-83.

Ashwal, L.D., Solanki, A.M., Pandit, M.K., Corfu, F., Hendriks, B.W.H., Burke, K. and Torsvik, T.H., 2013. Geochronology and geochemistry of Neoproterozoic Mt. Abu granitoids, NW India: Regional correlation and implications for Rodinia paleogeography. Precambrian Research, 236: 265-281.

Bauer, W., Walsh, G.J., de Waele, B., Thomas, R.J., Horstwood, M.S.A., Bracciali, L., Schofield, D.I., Wollenberg, U., Lidke, D.J., Rasaona, I.T. and Rabarimanana, M.H., 2011. Cover sequences at the northern margin of the Antongil Craton, NE Madagascar. Precambrian Research, 189(3-4): 292-312.

BGS-USGS-GLW, 2008. Republique de Madagascar Ministère de L'engergie et des Mines (MEM/SG/DG/UCP/PGRM). British Geological Survey Research Report.

Bindeman, I.N. and Valley, J.W., 2001. Low- $\delta 180$ rhyolites from Yellowstone: Magmatic evolution based on analyses of zircons and individual phenocrysts. Journal of Petrology, 42(8): 1491-1517.

Blades, M.L., Collins, A.S., Foden, J., Payne, J.L., Xu, X., Alemu, T., Woldetinsae, G., Clark, C. and Taylor, R.J.M., 2015. Age and hafnium isotopic evolution of the Didesa and Kemashi Domains, western Ethiopia. Precambrian Research, 270: 267-284.

Boger, S.D., Hirdes, W., Ferreira, C.A.M., Schulte, B., Jenett, T. and Fanning, C.M., 2014. From passive margin to volcano-sedimentary forearc: The Tonian to Cryogenian evolution of the Anosyen Domain of southeastern Madagascar. Precambrian Research, 247: 159-186.

Buchwaldt, R., Tucker, R.D. and Dymek, R.F., 2003. Geothermobarometry and U-Pb Geochronology of metapelitic granulites and pelitic migmatites from the Lokoho region, Northern Madagascar. American Mineralogist, 88(11-12): 1753-1768.

Collins, A.S., 2006. Madagascar and the amalgamation of Central Gondwana. Gondwana Research, 9(1-2): 3-16.

Collins, A.S., Fitzsimons, I.C.W., Hulscher, B. and Razakamanana, T., 2003a. Structure of the eastern margin of the East African Orogen in central Madagascar. Precambrian Research, 123(2-4): 111-133.

Collins, A.S., Kröner, A., Fitzsimons, I.C.W. and Razakamanana, T., 2003b. Detrital footprint of the Mozambique ocean: U-Pb SHRIMP and Pb evaporation zircon geochronology of metasedimentary gneisses in eastern Madagascar. Tectonophysics, 375(1-4): 77-99.

Collins, A.S. and Pisarevsky, S.A., 2005. Amalgamating eastern Gondwana: The evolution of the Circum-Indian Orogens. Earth-Science Reviews, 71(3-4): 229-270.

Collins, A.S. and Windley, B.F., 2002. The tectonic evolution of central and northern Madagascar and its place in the final assembly of Gondwana. The Journal of geology, 110(3): 325-339.

Condie, K.C., 2002. Breakup of a Paleoproterozoic supercontinent. Gondwana Research, 5(1): 41-43.

Cox, R., Armstrong, R.A. and Ashwal, L.D., 1998. Sedimentology, geochronology and provenance of the Proterozoic Itremo Group, central Madagascar, and implications for pre-Gondwana palaeogeography. Journal of the Geological Society, 155(6): 1009-1024.

Cox, R., Coleman, D.S., Chokel, C.B., DeOreo, S.B., Wooden, J.L., Collins, A.S., De Waele, B. and Kröner, A., 2004. Proterozoic Tectonostratigraphy and Paleogeography of Central Madagascar Derived from Detrital Zircon U-Pb Age Populations. The Journal of geology, 112(4): 379-399.

De Waele, B., Thomas, R.J., Horstwood, M., Pitfield, P., Tucker, R., Potter, C., Key, R., Smith, R., Bauer, W. and Randriamananjara, T., 2008. U-Pb detrital zircon geochronological provenance patterns of supracrustal successions in central and northern Madagascar.

De Waele, B., Thomas, R.J., Macey, P.H., Horstwood, M.S.A., Tucker, R.D., Pitfield, P.E.J., Schofield, D.I., Goodenough, K.M., Bauer, W., Key, R.M., Potter, C.J., Armstrong, R.A., Miller, J.A., Randriamananjara, T., Ralison, V., Rafahatelo, J.M., Rabarimanana, M. and Bejoma, M., 2011 . Provenance and tectonic 
significance of the Palaeoproterozoic metasedimentary successions of central and northern Madagascar. Precambrian Research, 189(1-2): 18-42.

Emmel, B., Jons, N., Kroner, A., Jacobs, J., Wartho, J.A., Schenk, V., Razakamanana, T. and Austegard, A., 2008. From Closure of the Mozambique Ocean to Gondwana Breakup: New Evidence from Geochronological Data of the Vohibory Terrane, Southwest Madagascar. The Journal of Geology, 116(1): 21-38.

Fernandez, A., Schreurs, G., Villa, I.M., Huber, S. and Rakotondrazafy, M., 2003. Age constraints on the tectonic evolution of the Itremo region in Central Madagascar. Precambrian Research, 123(2-4): 87-110.

Fitzsimons, I.C.W. and Hulscher, B., 2005. Out of Africa: detrital zircon provenance of central Madagascar and Neoproterozoic terrane transfer across the Mozambique Ocean. Terra Nova, 17(3): 224-235.

Fritz, H., Abdelsalam, M., Ali, K.A., Bingen, B., Collins, A.S., Fowler, A.R., Ghebreab, W., Hauzenberger, C.A., Johnson, P.R., Kusky, T.M., Macey, P., Muhongo, S., Stern, R.J. and Viola, G., 2013. Orogen styles in the East African Orogen: A review of the Neoproterozoic to Cambrian tectonic evolution. Journal of African Earth Sciences, 86: 65-106.

Frost, B.R. and Frost, C.D., 2008. A geochemical classification for feldspathic igneous rocks. Journal of Petrology, 49(11): 1955-1969.

Goodenough, K.M., Thomas, R.J., De Waele, B., Key, R.M., Schofield, D.I., Bauer, W., Tucker, R.D., Rafahatelo, J.M., Rabarimanana, M., Ralison, A.V. and Randriamananjara, T., 2010. Post-collisional magmatism in the central East African Orogen: The Maevarano Suite of north Madagascar. Lithos, 116(1-2): 18-34.

Huang, X.-L., Xu, Y.-G., Li, X.-H., Li, W.-X., Lan, J.-B., Zhang, H.-H., Liu, Y.-S., Wang, Y.-B., Li, H.-Y. and Luo, Z.-Y., 2008. Petrogenesis and tectonic implications of Neoproterozoic, highly fractionated A-type granites from Mianning, South China. Precambrian Research, 165(3-4): 190-204.

Jacobs, J., Elburg, M., Läufer, A., Kleinhanns, I.C., Henjes-Kunst, F., Estrada, S., Ruppel, A.S., Damaske, D., Montero, P. and Bea, F., 2015. Two distinct late Mesoproterozoic/early Neoproterozoic basement provinces in central/eastern Dronning Maud Land, East Antarctica: The missing link, 15-21 E. Precambrian Research, 265: 249-272.

Jöns, N., Emmel, B., Schenk, V. and Razakamanana, T., 2009. From orogenesis to passive margin—the cooling history of the Bemarivo Belt (N Madagascar), a multi-thermochronometer approach. Gondwana Research, 16(1): 72-81.

Jöns, N. and Schenk, V., 2007. Relics of the Mozambique Ocean in the central East African Orogen: evidence from the Vohibory Block of southern Madagascar. Journal of Metamorphic Geology, 0(0): 071115150845002 ???

Kröner, A., Hegner, E., Collins, A.S., Windley, B.F., Brewer, T.S., Razakamanana, T. and Pidgeon, R.T., 2000. Age and magmatic history of the Antananarivo Block, central Madagascar, as derived from zircon geochronology and Nd isotopic systematics. American Journal of Science, 300(4): 251-288.

Long, X., Yuan, C., Sun, M., Kröner, A., Zhao, G., Wilde, S. and Hu, A., 2011. Reworking of the Tarim Craton by underplating of mantle plume-derived magmas: evidence from Neoproterozoic granitoids in the Kuluketage area, NW China. Precambrian Research, 187(1-2): 1-14.

Mallard, C., Coltice, N., Seton, M., Müller, R.D. and Tackley, P.J., 2016. Subduction controls the distribution and fragmentation of Earth's tectonic plates. Nature, 535(7610): 140.

Merdith, A.S., Collins, A.S., Williams, S.E., Pisarevsky, S., Foden, J.D., Archibald, D.B., Blades, M.L., Alessio, B.L., Armistead, S. and Plavsa, D., 2017. A full-plate global reconstruction of the Neoproterozoic. Gondwana Research, 50: 84-134.

Morag, N., Avigad, D., Gerdes, A., Belousova, E. and Harlavan, Y., 2011. Crustal evolution and recycling in the northern Arabian-Nubian Shield: New perspectives from zircon Lu-Hf and U-Pb systematics. Precambrian Research, 186(1-4): 101-116.

Nance, R.D., Murphy, J.B. and Santosh, M., 2014. The supercontinent cycle: a retrospective essay. Gondwana Research, 25(1): 4-29.

Qi, X., Zeng, L., Zhu, L., Hu, Z. and Hou, K., 2012. Zircon U-Pb and Lu-Hf isotopic systematics of the Daping plutonic rocks: implications for the Neoproterozoic tectonic evolution of the northeastern margin of the Indochina block, Southwest China. Gondwana Research, 21(1): 180-193.

Robinson, F.A., Foden, J.D., Collins, A.S. and Payne, J.L., 2014. Arabian Shield magmatic cycles and their relationship with Gondwana assembly: Insights from zircon U-Pb and Hf isotopes. Earth and Planetary Science Letters, 408: 207-225.

Roig, J., Tucker, R., Delor, C., Peters, S. and Théveniaut, H., 2012. Carte géologique de la République de Madagascar à 1/1 000 000. Ministère des Mines, PGRM, Antananarivo, République de Madagascar, 1.

Schofield, D.I., Thomas, R.J., Goodenough, K.M., De Waele, B., Pitfield, P.E.J., Key, R.M., Bauer, W., Walsh, G.J., Lidke, D.J. and Ralison, A.V., 2010. Geological evolution of the Antongil Craton, NE Madagascar. Precambrian Research, 182(3): 187-203.

Sun, S.-S. and McDonough, W.-S., 1989. Chemical and isotopic systematics of oceanic basalts: implications for mantle composition and processes. Geological Society, London, Special Publications, 42(1): 313-345.

Thomas, R.J., De Waele, B., Schofield, D.I., Goodenough, K.M., Horstwood, M., Tucker, R., Bauer, W., Annells, R., Howard, K., Walsh, G., Rabarimanana, M., Rafahatelo, J.M., Ralison, A.V. and Randriamananjara, T., 2009. 
Geological evolution of the Neoproterozoic Bemarivo Belt, northern Madagascar. Precambrian Research, 172(3-4): 279-300.

Tucker, R., Ashwal, L., Hamilton, M., Torsvik, T. and Carter, L., 1999a. Neoproterozoic silicic magmatism of northern Madagascar, Seychelles, and NW India: clues to Rodinia's assembly and dispersal, Geological Society of America, Abstracts with Programs, pp. 317.

Tucker, R., Ashwal, L., Handke, M., Hamilton, M., Le Grange, M. and Rambeloson, R., 1999b. U-Pb geochronology and isotope geochemistry of the Archean and Proterozoic rocks of north-central Madagascar. The Journal of Geology, 107(2): 135-153.

Tucker, R., Ashwal, L. and Torsvik, T., 2001. U-Pb geochronology of Seychelles granitoids: a Neoproterozoic continental arc fragment. Earth and Planetary Science Letters, 187(1-2): 27-38.

Tucker, R., Roig, J.-Y., Delor, C., Amelin, Y., Goncalves, P., Rabarimanana, M., Ralison, A. and Belcher, R., 2011. Neoproterozoic extension in the Greater Dharwar Craton: a reevaluation of the "Betsimisaraka suture" in Madagascar. Canadian Journal of Earth Sciences, 48(2): 389-417.

Tucker, R.D., Roig, J.Y., Moine, B., Delor, C. and Peters, S.G., 2014. A geological synthesis of the Precambrian shield in Madagascar. Journal of African Earth Sciences, 94: 9-30.

Valley, J.W., Kinny, P.D., Schulze, D.J. and Spicuzza, M.J., 1998. Zircon megacrysts from kimberlite: oxygen isotope variability among mantle melts. Contributions to mineralogy and petrology, 133(1-2): 1-11.

Vervoort, J.D., Patchett, P.J., Blichert-Toft, J. and Albarède, F., 1999. Relationships between Lu-Hf and Sm-Nd isotopic systems in the global sedimentary system. Earth and Planetary Science Letters, 168(1): 79-99.

Wang, W., Cawood, P.A., Zhou, M.F., Pandit, M.K., Xia, X.P. and Zhao, J.H., 2017. Low- $\delta 180$ Rhyolites From the Malani Igneous Suite: A Positive Test for South China and NW India Linkage in Rodinia. Geophysical Research Letters, 44(20).

Wang, Y., Zhang, A., Cawood, P.A., Fan, W., Xu, J., Zhang, G. and Zhang, Y., 2013. Geochronological, geochemical and Nd-Hf-Os isotopic fingerprinting of an early Neoproterozoic arc-back-arc system in South China and its accretionary assembly along the margin of Rodinia. Precambrian Research, 231: 343-371.

Zhao, J.-H., Zhou, M.-F. and Zheng, J.-P., 2013. Constraints from zircon U-Pb ages, O and Hf isotopic compositions on the origin of Neoproterozoic peraluminous granitoids from the Jiangnan Fold Belt, South China. Contributions to Mineralogy and Petrology, 166(5): 1505-1519.

Zheng, Y.-F., Wu, R.-X., Wu, Y.-B., Zhang, S.-B., Yuan, H. and Wu, F.-Y., 2008. Rift melting of juvenile arc-derived crust: geochemical evidence from Neoproterozoic volcanic and granitic rocks in the Jiangnan Orogen, South China. Precambrian Research, 163(3): 351-383.

Zheng, Y.-F., Zhang, S.-B., Zhao, Z.-F., Wu, Y.-B., Li, X., Li, Z. and Wu, F.-Y., 2007. Contrasting zircon Hf and O isotopes in the two episodes of Neoproterozoic granitoids in South China: implications for growth and reworking of continental crust. Lithos, 96(1-2): 127-150.

Zhou, J.-L., Li, X.-H., Tang, G.-Q., Liu, Y. and Tucker, R.D., 2018. New evidence for a continental rift tectonic setting of the Neoproterozoic Imorona-Itsindro Suite (central Madagascar). Precambrian Research, 306: 94-111.

Zhu, D.-C., Zhao, Z.-D., Niu, Y., Dilek, Y. and Mo, X.-X., 2011. Lhasa terrane in southern Tibet came from Australia. Geology, 39(8): 727-730. 